\title{
治水計画規模の決定に関するゲーム論的研究
}

\section{Game Theory on Decision Problem of the Project Scale for Flood Prevention Works.}

$\begin{array}{lllll}\text { 侏日本水道コンサルタント } & \text { 正員 } \bigcirc \text { 中 } & \text { 芳 } & \\ \text { 国土 庁 } & \text { 正員 飯 塚 敏 夫 } \\ \text { 建 設 省 } & \text { 正員 梅 } & \text { 本 良 平 }\end{array}$

1. はじめに

本稿では、種々の治水計画の目的達成手段のうち、河道での洪水防御計画を対象として、経済的妥当性と いう観点からの規模決定法について考察する。

洪水防御計画規模の決定は、基本的には計画主体の意志決定問題として把握される。このとき、洪水の外 力としての水文現象の生起技よびそれと災害との関連を明確にし、いかなる評価基準のもとで計画規模を決 定するかが重要な問題となる。ところで、この水文現象すなわち降雨現象あるいは流出現象などは不確定な 性状が強く、これらの現象の生起飞係わる不確定性の取り扱いに関しては、確率統計的方法が有力である。 しかし、洪水防御計画に扣いて問題となるのは生起頻度がきわめて小さな極大值近傍の領域の水文事象であ り、洪水ピーク時の観測の困難さや統計データの集積の不十分なことなどにより、水文量の生起確率の推定 結果の適用に当っては、その信頼度について十分な検討が必要とされょう。

このため、本稿では、このような確率の信頼度を考慮した洪水防御計画の規模決定モデルを、ゲーム論的 概念を応用して定式化するとともに、そのモデルを実際河川へ適用した結果を述べる。

まず、2.では、計画規模決定問題を、不完全情報下に打ける意志決定問題として取り扱い、ゲーム論的ア プローチにょり、経済評価による計画規模決定モデルを定式化する。ついで、3.では、2.で定式化した計画 規模決定モデルを $\mathrm{Y} 川$ 流域に適用し、基準地点に扣ける最適高水流量として計画規模の算定を種々の条件の もとで行ない、その結果を比較・検討する。

2. 計画規模決定モデル

$2-1$. 概 説

治水計画規模の評価基準としては、河川の重要度、既往洪水規模、経済効果など多くの基準が考えられる。 ここでは、人命の保護と施設・物件の防護とは分離して取り扱い、施設・物件に対しては、治水事業を経済 活動の一要素としてとらえ、経済的妥当規模を治水計画の目標とする立場にたつ。こうして決定された計画 規模を越える洪水が発生した場合には、水防、避難などの間接防御方式により、人命に対する完全防御。無 被害を目指すとした立場を根底としている。

また、計画の基本量としては、ここでの対象が河道での洪水防御計画であるから、洪水のピーク流量を採 用することとする。このとき、1.で述べた理由で、ピーク流量の生起確率密度関数にひとつの理論分布をあ てはめることが困難な場合も生じ、水文資料の信頼度を計画規模の決定に扎いてどのように考虑するかは重 大な問題となる。このため、ここでは、計画規模決定問題を、洪水のピーク流量の確率密度関数に関する情 報が十分でないとした場合、すなわち不完全情報下に打ける意志決定問題として取り报うこととする。具体 的には、ゲーム論的アプローチ1）により計画規模決定モデルを定式化する。

な打、ここでいう不完全情報とは、基準地点のピーク流量の期待值打よび偏差は既知であるが、分布形そ のものは未知であるというように、ある確率変数の分布形 ( 確率密度関数) を決定するための情報が十分で ない場合を意味している。

2-2. モデルの定式化とアルゴリズム

いま、洪水による被害額が、洪水のピーク流量のみの関数として一義的に定まるとすれば、計画高水流量 $\mathrm{q}$ を越える洪水による年平均被害額の期待値は、次式で表わされる。 


$$
E\{D(q)\}=r \cdot \int_{q}^{\infty} D(y) \cdot f(y) d y
$$

ここK、 $\mathrm{E}\{\mathrm{D}(\mathrm{q})\}$; 高水流量が計画流量規模 $\mathrm{q}$ を越える場合の年平均被害額期待值、 $\mathrm{D}(\mathrm{y})$; 高水流量が $\mathrm{y}$ の場合の想定被害額 (以下、 $\mathrm{D}-\mathrm{Q}$ 曲線 と呼 5 ) 、 $\mathrm{f}(\mathrm{y})$; 高水流量 $\mathrm{y}$ の生起確率密度関数、 $\mathrm{r}$; 年平均洪水 生起回数、である。

この被害額の期待值は、この計画の達成結果に対して国民がやむを得ず支払わねばならない費用（対価） とみなすことができる。一方、この計画を達成するための事業費が $\mathrm{q}$ の関数で表わされれば、これら両者の 和が、この流量規模 $\mathrm{q}$ の計画の結果国民の支払う総費用期待值といらことがでさる。すなわら、

$$
E\{C(q)\}=G(q)+K \cdot E\{D(q)\}=G(q)+K \cdot r \cdot \int_{q}^{\infty} D(y) \cdot f(y) d y
$$

ここK、 $\mathrm{E}\{\mathrm{C}(\mathrm{q})\}$; 流量規模 $\mathrm{q}$ の計画の年平均総費用期待值、 $\mathrm{G}(\mathrm{q})$; 流量規模 $\mathrm{q}$ の計画の年平均事業費 (以下、 $\mathrm{G}-\mathrm{Q}$ 曲線と呼ふ）、 $\mathrm{K}$; 換算係数、である。(1)式で表わされる $\mathrm{E}\{\mathrm{D}(\mathrm{q})\}$ は、直接被害 $\mathrm{D}(\mathrm{q})$ のみ を対象とし、間接被害は含まれていない。そこで、この間接被害を総費用期待值の算定に颃いて勘案するた めに導入したのが換算係数 Kであり、この K は間接被害をも含めた総被害額が直接被害額の何倍であるかを 示す数值である。

ここで、上述のよ5にピーク流量 $\mathrm{q}$ の想定被害額 $\mathrm{D}(\mathrm{q})$ は $\mathrm{q}$ の関数として定まるので、洪水 $\mathrm{j}$ のピーク流量 代表值 $q_{j}$ (この $q_{j}$ は、3.で述べるら 、、ピーク流量の実測值、または洪水調節後のピーク流量計算値 を用いる）飞対応して、洪水 $\mathrm{j}$ による想定被害額 $\mathrm{D}_{\mathrm{j}}$ が一義的に定まる。この被害額の分布形扣よび期待值、 偏差を、それぞれ h (D)よび $m_{\mathrm{D}} 、 \sigma_{\mathrm{D}}$ と記す。

一般にピーク流量の分布形 $\mathrm{f}(\mathrm{q})$ としては、グンベル分布、対数正規分布などが適合するといわれるが、2 ー 1. で述べたよ 5 に、ひとつの理論分布形を画一的にあてはめることが難しいことも多い。したがって、

$\mathrm{f}(\mathrm{q})$ 抢よび $\mathrm{D}(\mathrm{q})$ より定まる被害額の分布形 $\mathrm{h}$ (D) 亿単一の理論分布形を想定することもまた無理が多い。そと で、2-1. で述べた不完全情報の場合、すなわち被害額の期待值 $m_{\mathrm{D}}$ と偏差 $\sigma_{\mathrm{D}}$ は既知であるが、その分布形 $\mathrm{h}(\mathrm{D})$ は未知であると考光、ゲーム論的アプローチにより最適な高水流量許模 $\mathrm{q}$ を決めることとする。この手順は、 以下のようである。

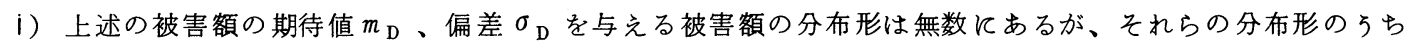
(2)式で与えられる総費用期待值 $\mathrm{E}\{\mathrm{C}$ (q) $\}$ を最大とする、換言すれば計画主体にとって最も不都合な分布 形を考える。すなわち、

$$
\max _{h} E\{C(q)\}
$$

を与える分布形 $\mathrm{h}(\mathrm{D})$ を考えることになる。

ii） i の上そ計画主体にとって最も不都合な分布形が出現したという状況下で、総費用期待值 $\mathrm{E}\{\mathrm{C}(\mathrm{q})\}$ を最小とする高水流量 $\mathrm{q}$ の值を求める。すなわち、

$$
\min _{q} \max _{h} E\{C(q)\}
$$

を与える q を求め、この $\mathrm{q}$ を最適高水流量とよぶ。

こうして、総費用期待值最小という意味での最適高水流量を決定するモデルは、(4)式を满足する高水流量 qを決定する問題として定式化できた。な打、(4)式は、自然と計画主体の 2 人ゲームを構成する式とるいえ る。以下では、この式の解法を明らかにする。

まず、想定被害額の期待值 $m_{\mathrm{D}}$ 抢よび $\sigma_{\mathrm{D}}$ は既知であるから、期待值 $m_{\mathrm{D}}$ より大きい被害額 $\mathrm{D}$ は、

$$
D=m_{D}+k \cdot \sigma_{D}, k>0
$$

と表わせる。この被害額 $\mathrm{D}$ を発生させる高水のピーク流量 $\mathrm{q} は 、 \mathrm{D}-\mathrm{Q}$ 曲線より求まり、これを、

$$
q=Q\left(m_{D}+k \cdot \sigma_{D}\right)
$$

のようと表わす。(6)式は、qが $\mathrm{k}$ の関数として表わされることを示しており、この式を用いて(2)式を書き直 すと、

$$
E\{C(q)\}=G\left(Q\left(m_{D}+k \cdot \sigma_{D}\right)\right)+K \cdot r \cdot \int_{Q\left(m_{D}+k \cdot \sigma_{D}\right)}^{\infty} D(y) \cdot f(y) d y
$$


となる。ここで、 $\mathrm{D}-\mathrm{Q}$ 曲線より $\mathrm{q}=\mathrm{Q}$ (D) と、 $\mathrm{q}$ は D の関数ともみなせるから、(7)式の右辺の積分は、

$$
I=\int_{Q\left(m_{D+k} \cdot \sigma_{D}\right)}^{\infty} D(y) \cdot f(y) d y=\int_{m_{D+k} \cdot \sigma_{D}}^{\infty} D \cdot h(D) d D
$$

と、被害額 D関する積分となり、この積分は、さらに

と変形される。

$$
\begin{aligned}
I & =\sum_{i=0}^{\infty}\left\{\int_{m_{D}+(k+i) \sigma_{D}}^{m_{D+(k+i+1) \cdot \sigma_{D}}} D \cdot h(D) d D\right\} \leqq \sum_{i=0}^{\infty}\left(m_{D}+(k+i+1) \sigma_{D}\right) \cdot \int_{m_{D}+(k+i) \cdot \sigma_{D}}^{m_{D}+(k+i+1) \cdot \sigma_{D}} h(D) d D \\
& =\left(m_{D}+k \cdot \sigma_{D}\right) \int_{m_{D}+k \cdot \sigma_{D}}^{\infty} h(D) d D+\sigma_{D} \cdot \sum_{i=0}^{\infty}\left\{\int_{m_{D}+(k+i) \cdot \sigma_{D}}^{\infty} h(D) d D\right\}
\end{aligned}
$$

$$
\text { ところで、 } \quad \int_{m_{D}+(k+i) \cdot \sigma_{D}}^{\infty} h(D) d D=P\left\{D \geqq m_{D}+(k+i) \cdot \sigma_{D}\right\}
$$

であり、上式の右辺の確率にチェビシェフの不等式を適用すると、

$$
\int_{m_{D}+(k+i) \cdot \sigma_{D}}^{\infty} h(D) d D \leqq 1 /(k+i)^{2}
$$

が得られ、(9)式飞代入すれば、

$$
I \leqq\left(m_{D}+k \cdot \sigma_{D}\right) / k^{2}+\sigma_{D} \cdot \sum_{i=0}^{\infty} 1 /(k+i)^{2}
$$

となり、結局(7)式の右辺第 2 項の積分が(12)式で与えられる。したがって、(7)式の総費用期待值については、 次式が成り立つ。

$$
E\{C(q)\} \leqq G\left(Q\left(m_{D}+k \cdot \sigma_{D}\right)\right)+K \cdot r \cdot\left\{\left(m_{D}+k \sigma_{D}\right) / k^{2}+\sigma_{D} \cdot \sum_{i=0}^{\infty} 1 /(k+i)^{2}\right\}
$$

本モデルでは、 $\mathrm{h}(\mathrm{D})$ の分布形が未知であると考えた。そこで、

$$
\max _{h} E\{C(q)\}=G\left(Q\left(m_{D}+k \cdot \sigma_{D}\right)\right)+K \cdot r \cdot\left\{\left(m_{D}+k \cdot \sigma_{D}\right) / k^{2}+\sigma_{D} \cdot \sum_{i=0}^{\infty} 1 /(k+i)^{2}\right\}
$$

となり、 $\min _{q} \max _{h} E\{C(q)\}$ を与光る最適高水流量 $\mathrm{q}^{*}$ は、(14)式が $\mathrm{k}$ に関して下に凸となることから、つぎの

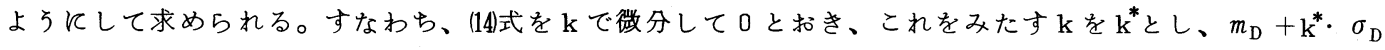
に対応する高水流量 qを(6)式より求めれば良い。

な打、(14)式の右辺の級数をそのまま微分することは不可能であるから、つぎのような近似を行なら。すな わち、オイラー・マクローリン公式を $\sum_{i=0}^{\infty} 1 /(k+i)^{2}$ 亿適用すると、

$$
\sum_{i=0}^{\infty} 1 /(k+i)^{2}=1 / k^{2}+1 / 2 k^{2}+1 / 6 k^{3}+\cdots \cdots
$$

となり、(14)式に上式の右辺第了項までの近似を採用すれば、

$$
\max _{h} E\{C(q)\} \doteqdot G\left(Q\left(m_{D}+k \cdot \sigma_{D}\right)\right)+K \cdot r \cdot\left\{m_{D} / k^{2}+\sigma_{D} \cdot\left(2 / k+1 / 2 k^{2}+1 / 6 k^{3}\right)\right\}
$$

となるのて、、具体的な算定が可能となる。

2-3. 複数個の基準地点を対象とした場合へのモデルの拡張

洪水防御計画の策定にあたって、同一水系内飞複数個の基準地点のある場合、地点間で計画規模の整合性 が計られる必要がある。ところで、2-2.で定式化したモデルは、単一の基準地点を対象としたものであっ た。そこで、ここでは、2-2.の単一基準地点でのモデルを複数個の基準地点を同時に対象とした場合へ拡 張する。

ここでのモデルの基本的な考光方は、2 2-2.で述べた単一基準地点でのものと同様である。ただし、後述 するように基準地点間の整合性の考虑を、各基準地点の高水流量間の制約条件として導入したため。本モデ ルはいわゆる条件付非線形計画モデルとして表現される。

いま、対象水系の本川飞 $\mathrm{n}$ 個の基準地点があるとする。各基準地点での計画流量規模を $\mathrm{q}^{1} 、 \mathrm{q}^{2} 、 \cdots 、 \mathrm{q}^{\mathrm{n}}$ と すると、水系全体での年平均総費用期待值 $\mathrm{E}\left\{\mathrm{C}\left(\mathrm{q}^{1} 、 \mathrm{q}^{2} 、 \cdots 、 \mathrm{q}^{\mathrm{n}}\right)\right\}$ は、(2)式を多変数の場合一拡張して、 $E\left\{C\left(q^{1}, q^{2}, \cdots, q^{n}\right)\right\}=G\left(q^{1}, q^{2}, \cdots, q^{n}\right)+K \cdot r \cdot \int_{q^{1}}^{\infty} \int_{q^{2}}^{\infty} \cdots \int_{q^{n}}^{\infty} D\left(y^{1}, y^{2}, \cdots, y^{n}\right) \cdot f\left(y^{1}, y^{2}, \cdots, y^{n}\right) d y^{1} d y^{2} \cdots d y^{n}$ (17) となる。

つぎ、、基準地点間の計画規模の整合性の問題について考察する。ここでは、この整合性を各基準点間で の計画高水流量規模の整合性で代表させ、各基準地点の高水流量間の制約条件として以下のょうに定式化す る。すなわら、各基準地点間の高水流量は独立ではあり得ないから、ある基準地点での高水流量を最近接上 流基準地点での高水流量で表わすことを考え、それを用いて各基準地点の高水流量間の制約条件を、アルゴ 
リズムの簡略化の便宣も考えて、次式の一次式とした。

$$
\alpha_{i-1}^{2} \cdot q^{i-1}+\beta_{i-1}^{2} \leqq q^{i} \leqq \alpha_{i-1}^{1} \cdot q^{i-1}+\beta_{i-1}^{1} \quad(i=1,2, \cdots, n)
$$

ここに、 $\alpha_{i}^{\ell}, \beta_{i}^{\ell}$ そは河道での洪水の伝播、残流域流入扣よび合流などの諸特性が集約されていると考えら れ、これらは洪水追跡計算あるいは実測データの統計処理などにより推算でさよう。

ここで、越過洪水による年平均被害額は基準地点ごとに独立に算定される、すなわら基準地点ごとに氾濫 域が存在し各域が洪水氾濫現象に関して独立と仮定し、各氾濫域の想定被害額は対応する基準地点の高水流 量 $\mathrm{q}^{\mathrm{i}}$ のみの関数とする。以上の仮定のもとで、(17)式は次式のように書ける。

$$
E\left\{C\left(q^{1}, q^{2}, \cdots, q^{n}\right)\right\}=G\left(q^{1}, q^{2}, \cdots, q^{n}\right)+r \cdot \sum_{i=1}^{n} K^{i} \cdot \int_{q^{i}}^{\infty} D^{i}(y) \cdot f^{i}(y) d y
$$

ここに、 $\mathrm{D}^{\mathrm{i}}(\mathrm{y})$; 基準地点 $\mathrm{i}$ での高水流量が $\mathrm{y}$ の場合の想定被害額、 $\mathrm{f}^{\mathrm{i}}(\mathrm{y})$; 基準地点 $\mathrm{i}$ での高水流量 $\mathrm{y}$ の生起 確率密度関数、 $\mathrm{K}^{\mathrm{i}}$; 換算係数、である。

地点 $\mathrm{i}$ での洪水のピーク流量が $q$ の場合の想定被害額 $D^{i}\left(q^{i}\right)$ は $q^{i}$ みの関数としたから、洪水 $\mathrm{j}$ の地点

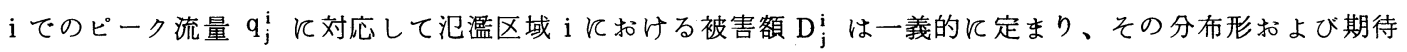
值、偏差を $\mathrm{h}^{\mathrm{i}}\left(\mathrm{D}^{\mathrm{i}}\right) 、 m_{\mathrm{D}}^{\mathrm{i}} 、 \sigma_{\mathrm{D}}^{\mathrm{i}}(\mathrm{i}=1,2, \cdots, \mathrm{n})$ で表わす。

こうして、191式を評価式として、想定被額額の期待值 $m_{\mathrm{D}}^{\mathrm{i}}$ と偏差 $\sigma_{\mathrm{D}}^{\mathrm{i}}$ は既知であるが、その分布形 $\mathrm{h}^{\mathrm{i}}\left(\mathrm{D}^{\mathrm{i}}\right)$ は未知であるという不完全情報下に扣いて、各基準地点間の計画規模の整合性を考慮した最適高水流量の組 み合せ $\left(\mathrm{q}^{{ }^{*}} 、 \mathrm{q}^{2^{*}} 、 \cdots 、 \mathrm{q}^{\mathrm{n}}{ }^{*}\right)$ を決定するモデルは、2-2.と同様の考えのもとで(18)式をみたす各基準地 点の高水流量の変動領域の内で、

$$
\min _{\left\{q^{1}, q^{2}, \cdots, q^{n}\right\}\left\{h^{1}, h^{2}, \cdots, h^{n}\right\}} E\left\{C\left(q^{1}, q^{2}, \cdots, q^{n}\right)\right\}
$$

を与える高水流量の組み合せ $\left(\mathrm{q}^{1} 、 \mathrm{q}^{2} 、 \cdots 、 \mathrm{q}^{\mathrm{n}}\right)$ を求める問題として定式化できる。

な打、このモデルの解法は、基本的には $2-2$.で述べたものと同じとなるので省略する。

3. 計画規模決定モデルの適用例

3ー1. 演算ケース抢よび入カデータ

ここでは、2.で定式化した計画規模決定モデルを、Y川流 域に適用した結果を述べる。図ー1亿その流域概要を示す。

洪水防御計画は、通常河道改修計画と洪水調節計画により 構成される。そこで、ここでは、6ケースの洪水調節計画を 考え、洪水調節を考えない場合と合わせて、合計 7 ケースの 図-1 Y 川流域の概要

演算を行なった。

このとき、洪水調節を考えた場合の年事業費 $\mathrm{G}(\mathrm{q})$ （または、G（ $\mathrm{q}^{1} 、 \mathrm{q}^{2} 、 \cdots 、$ $\mathrm{q}^{\mathrm{n}}$ ) ) は、河道改修飞要する事業費 $\mathrm{G}_{1}(\mathrm{q})$ (または、 $\mathrm{G}_{1}\left(\mathrm{q}^{1} 、 \mathrm{q}^{2} 、 \cdots 、 \mathrm{q}^{\mathrm{n}}\right.$ ) ) と 洪水調節飞要する事業費 $\mathrm{G}_{2}$ との和としている。な招、 $\mathrm{G}_{2}$ は基準地点の流量規模 $q$ には係わらず定数となるが、洪水調節ケースごとには異なる。

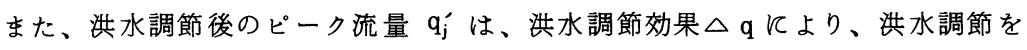
考えない場合のピーク流量を $\mathrm{q}_{\mathrm{j}}$ として、

$$
q_{j}^{\prime}=q_{j}-\Delta q
$$

(21)

と表わされるものと仮定し、さらに $\mathrm{q}$ は、 $\mathrm{q}_{\mathrm{j}}$ の線形関数と仮定している。

表一1. 演算ケース扣よび $\mathrm{G}_{2} 、 \triangle \mathrm{q}$

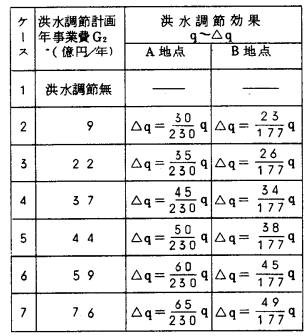

各演算ケースでの洪水調節計画年事業費 $\mathrm{G}_{2}$ 扣よび洪水調節効果 $\Delta \mathrm{q}$ を表ー 1 亿示す。

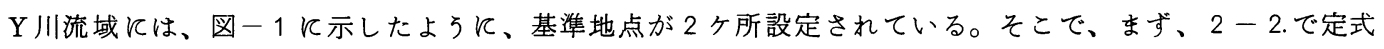
化した単一基準地点での計画規模決定モデルを適用して、A、B各基準地点での最適高水流量をそれぞれ独 立に算定する。ついで、2 - 3.で定式化した複数個の基準地点を対象とした計画規模決定モデルを適用して、 基準地点 $\mathrm{A} 、 \mathrm{~B}$ の最適高水流量を同時飞算定する。な掞、これらの最適高水流量の算定は、各々表一 1 に示 した 7 演算ケースについて行なら。 
$\mathrm{A} 、 \mathrm{~B}$ 両地点での $\mathrm{D}-\mathrm{Q}$ 曲線扣よび $\mathrm{G}-\mathrm{Q}$ 曲線 (河道 改修事業費）を図ー2 亿示す。な打、想定被害額の期待 值 $m_{\mathrm{D}}$ 、偏差 $\sigma_{\mathrm{D}}$ の算定は、各地点飞打ける昭和 29 51 年の年最大ピーク流量実測值扣よび洪水調節後のピ 一ク流量計算值（２３個）を標本として行なった。 $3-2$. 演算結果とその考察

1)まず、2-2. で定式化した単一基準地点での計画規 模決定モデルにより、A、B各基準地点での最適高水流 量をそれぞれ独立に算定した結果について述べる。この とき、換算係数 Kは、1.0 から 3.0 まで変動させ、各 $\mathrm{K}$ ごとに最適高水流量の算定を行なった。

図一 3 亿換算係数 $\mathrm{K}$ の各值に対する最適高水流量 $\mathrm{q}^{*}$ を ケース 1 とつて示す。

A 地点の最適高水流量 $\mathrm{q}^{*}$ は $23,100 \sim 38,500 \mathrm{~m}^{3} / \mathrm{sec}$ と、 B 地点の 14,600 16,800 $\mathrm{m}^{3} / \mathrm{sec}$ 比べて大きい。これは、図ー2の D-Q 曲線、 $\mathrm{G}-\mathrm{Q}$ 曲線にみられるように、同一流量に対する事業費 $\mathrm{G}$ に大 差はないが、A 地点の被害額 Dが B 地点のそれに比べてはるかに大きい ためである。また。このため超過洪水による被害額期待值 $\mathrm{E}\{\mathrm{D}(\mathrm{q})\}$ は、 $\mathrm{A}$ 地点での值は $\mathrm{B}$ 地点での值の 200 倍以上飞達し。総費用期待值 $\mathrm{E}\{\mathrm{C}$ (q) \} も、A 地点で1784 4894 億円/年と、B 地点の 7 2 81億円 /年 の 25 〜 6 倍となる。

つきれ、Kの変化による $\mathrm{q}^{*}$ 応答について検討する。 $\mathrm{A}$ 地点での $\mathrm{q}^{*}$ は、 $\mathrm{K}=1.0 \sim 2.0$ で約 $23,000 \mathrm{~m}^{3} / \mathrm{sec}$ と変化がなく、 $\mathrm{K}=2.0$ 以上ではほぼ線 形的な増加傾向を示す。また、B地点に执いては、Kの増加に伴い $q^{*}$ 。 増加するが、 $K=1.4$ - 1.6 間の増加は、他の区間に比べて大きい。この よ5な KKよる ${ }^{*}$ の変化に不連続点が生じる原因は、主として図ー2の $\mathrm{G}-\mathrm{Q}$ 曲線の形状 (旬配の急変点の存在) にあると考元られる。

このように、A地点に扣いては、Kを2.0をで増 大させても、すなわち間接被害を直接被害と同程度 まで勘案しても $q^{*}$ は変化しないが、B地点に打いて は、Kが1. 4 を越すと、すなわら間接被害を直接被 害の 4 割以上見込むと $q^{*} か ゙$ 急激に増加するという結 果となった。

以上の検討結果扣よび (他流域ではあるが) 間接 被害の推算例を参考にして、以下では、 $\mathrm{K}=1.4$ の 場合を例示的にとりあげて考祭することとする。

表 - 1 の各演算ケースでの最適高水流量算定結果 を図ー4 亿示す。

$\mathrm{A}$ 地点では、総費用期待值はケース 1 7 の順に 小さくなって扣り、総費用期待值の最小化という基 準のもとでは洪水調節を考えた方が良く、その内でも洪水調節効の大きいケース7の総費用期待值はケース 1 の約1/4となっている。また、q*はケース1〜 5 では約 $2,300 \mathrm{~m}^{3} / \mathrm{sec} 、 ケ ー ス 6 、 7 て ゙ は 18,000 ~ m^{3} / \mathrm{sec}$ とな

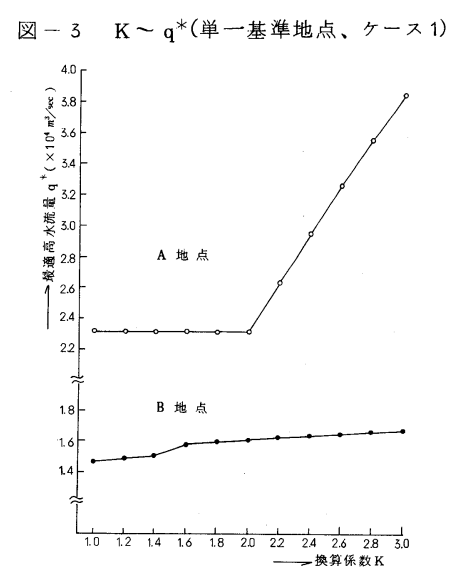

図一 4 各ヶースの最適高水流量、総費用期待値 扰よび事業費（単一基準地点、 $\mathrm{K}=1.4$ )




る。一方、 B 地点では、総費用期待值はケース1〜7の順に大きくなって抢り、総費用期待值の最小化とい 万基準のもとでは洪水調節を考えない方が良いといえる。な扣、q*はケース1〜7の順に小さくなっている。

このよ5に、A地点に扣いては、洪水調節を考えたケース2〜 7 が、洪水調節を考えないケース 1 に比べ て総費用期待值が小さくなり、B 地点に扔いては、逆にケース 1 がケース 2 ケより小さくなっている。こ の理由としては、A 地点に扣ける $\mathrm{E}\{\mathrm{D}(\mathrm{q})\}$ がケース 1 で約 1, 60 億円 $/$ 年と $\mathrm{G}_{2}$ の約 10 〜 0 億円 $/$ 年に比へ てはるかに大きく、洪水調節によって $\mathrm{E}\{\mathrm{D}(\mathrm{q})\}$ を隇少させる方が有利なのに対して、B地点ではケース 1 の $\mathrm{E}\{\mathrm{D}(\mathrm{q})\}$ が約 6 億円／年と $\mathrm{G}_{2}$ よりもかなり小さいため、巨費を要する洪水調節を考えない方が有利とな ることによると考えられる。な打、 $\mathrm{K} か ゙ 1.4$ 以外の場合も同様の結果となった。

2)つきれ、2-3.で定式化した複数個の基準地点を対象とした計画 図ー5 各ケースの最適高水流量、総費用期 規模決定モデルにより、A、B 両基準地点での最適高水流量を同時に 算定した結果について述へる。図ー1亿示したように、Y川流域では、 A、B 両基準地点ごとに氾濫域が存在し、この 2 つの氾監域は重複し ないとみてよいから、2 - 3.で述べた計画超過洪水による被害額が基 準地点ごとに独立に計量できるという仮定は許容される。また、基準 地点の流量規模の整合性に関する制約式は、A、B地点間の流量相関 より、

$$
0.757 \cdot q^{1}-2630.0 \leqq q^{2} \leqq 0.757 \cdot q^{1}+2757.0
$$

とした。ここに、 $\mathrm{q}^{1} 、 \mathrm{q}^{2}$ はそれぞれ $\mathrm{A} 、 \mathrm{~B}$ 地点の高水流量規模である。 図一 5 K、 $\mathrm{K}^{1}=\mathrm{K}^{2}=1.4$ の場合の各ヶースでの最適高水流量算定結 果を示す。

ケース1の $q^{*}$ は、 $\mathrm{A} 、 \mathrm{~B}$ 両地点とも1)で述べた単一基準地点の場 待值抢よび事業費 (水系全体、 $\mathrm{K}_{1}=\mathrm{K}_{2}=1.4$ )

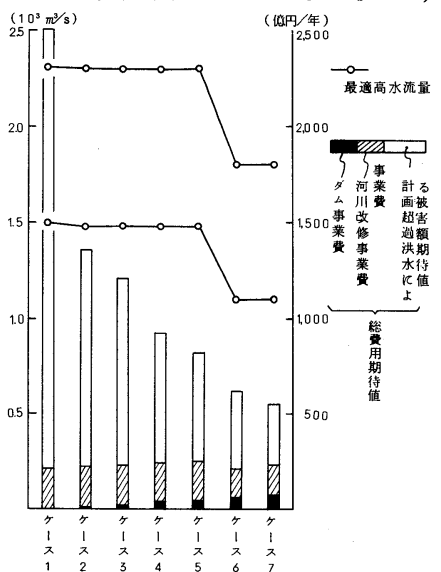
合と全く同一である。これに対し、ケース2〜 7 の*は、A地点では単一基準地点の場合と同じであるが、 B 地点では(22)式の制約により単一基準地点の場合より大きくなっている。

総費用期待值は、ケース1〜7の順に小さくなって扣り、総費用期待值の最小化という基準のもとでは洪 水調節を考えた方が良く、その内でもケース 7 が最良といえる。ケース 7 では、ケース 1 亿比べ総費用期待 值は約 $80 \%$ 減、 $\mathrm{q}^{*}$ はA 地点で約 $5.000 \mathrm{~m}^{3} / \mathrm{sec、B}$ 地点で約 $4,000 \mathrm{~m}^{3} / \mathrm{sec}$ 減となっている。

な打、 $\mathrm{K}^{1} 、 \mathrm{~K}^{2}$ が 1.4 以外の場合にも同様の結果となった。

\section{4. おわりに}

洪水防御計画に扣いて検討の対象となるのは生起確率のきわめて小さな極大值近傍の領域での水文諸量で あり、洪水ピーク時の観測が困難なこと、統計データの集積が不十分なことなどにょり水文量の生起確率の 推定精度に疑問が残る場合も多い。このため、本稿では、ゲーム論的概念を応用して、このような確率の信 頼度を考虑した計画規模決定法を提示した。すなわら、不完全情報下に打けるゲーム論的アプローチにより、 最適高水流量を経済評価により決定する計画規模決定モデルの定式化を行ない、そのアルゴリズムを示した。 ついで、このモデルをY川流域に適用し、基準地点に扣ける最適高水流量として計画規模の算定を種々の ケースについて行ない、その結果を比較・検討した。

こうして、洪水防御計画の規模決定の過程で洪水規模の確率密度関数に関する情報が不十分な場合にも、 ゲーム理論を適用することによって、計画規模決定問題をひとつの意志決定問題として解決しうることを明 らかにした。

最後に、本稿の作成にあたり御指導を賜わった京都大学教授岩佐義朗先生、名古屋工業大学教授長尾正志 先生に感謝いたします。また、熱心な討議を頂いた株日本水道コンサルタントの萩原良已、辻本善博の両氏 に謝意を表します。

〔参考文献〕 1) 松田正一他；O Rのための基礎数学 5 、丸善、1964 